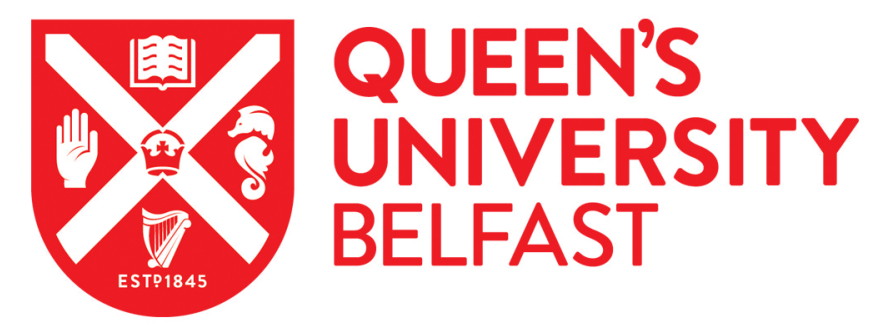

\title{
Accounting for the Public Sector at a Time of Crisis
}

Hyndman, N., \& McKillop, D. (2019). Accounting for the Public Sector at a Time of Crisis. Abacus: A Journal of Accounting, Finance and Business Studies, 55(3), 437-451. https://doi.org/10.1111/abac.12170

Published in:

Abacus: A Journal of Accounting, Finance and Business Studies

Document Version:

Peer reviewed version

Queen's University Belfast - Research Portal:

Link to publication record in Queen's University Belfast Research Portal

Publisher rights

(C) 2019 Accounting Foundation, The University of Sydney

This work is made available online in accordance with the publisher's policies. Please refer to any applicable terms of use of the publisher.

\section{General rights}

Copyright for the publications made accessible via the Queen's University Belfast Research Portal is retained by the author(s) and / or other copyright owners and it is a condition of accessing these publications that users recognise and abide by the legal requirements associated with these rights.

Take down policy

The Research Portal is Queen's institutional repository that provides access to Queen's research output. Every effort has been made to ensure that content in the Research Portal does not infringe any person's rights, or applicable UK laws. If you discover content in the Research Portal that you believe breaches copyright or violates any law, please contact openaccess@qub.ac.uk. 
Accepted Paper Abacus (Accepted June 2019)

\title{
Accounting for the Public Sector at a Time of Crisis
}

\author{
Queen's Authors' Details \\ Noel Hyndman and Donal McKillop \\ Queen's Management School \\ Queen's University Belfast \\ Riddel Hall \\ 185 Stranmillis Road \\ Belfast BT9 5EE \\ Northern Ireland, UK \\ Tel: +44 (0)2890974933 / +44 (0)2890974852 \\ E-mail: n.hyndman@qub.ac.uk/dg.mckillop@qub.ac.uk
}

\begin{abstract}
This Special Issue is based on papers initially presented at the 'Accounting for the Public Sector at a Time of Crisis' Conference at the Centre for Not-for-profit and Public-sector Research, Queen's University Belfast, UK in 2018. The public sector consists of organisations that are owned and operated by government; organisations that exist to provide goods and services for a country's citizens. What is particularly distinctive about such organisations, and what makes them different from businesses, is that they are (or, at least perhaps, should be) notfor-profit. In addition, they frequently have wide social and cultural goals that are central to what they do. They are pervasive in most societies. Yet, it is argued, they face crisis on a number of fronts: in terms of the influence of potentially-inappropriate, business-like New Public Management ideas related to performance management and the embracing of related accounting and budgeting approaches; and in terms of the impact of austerity, following the Great Recession in 2008. In such a context it is suggested that public-sector governance, accounting and accountability systems are heavily involved. The papers included in this Special Issue present an opportunity to reflect on aspects of this crisis in terms of how it connects with accounting systems and accounting changes. Key arguments of these papers, and overarching themes of this Special Issue, are explored in this editorial.
\end{abstract}

Key words: public sector; crisis; New Public Management; austerity

Noel Hyndman (n.hyndman@qub.ac.uk) and Donal McKillop (dg.mckillop@qub.ac.uk) are both from Queen's Management School, Queen's University, Belfast, Northern Ireland, UK. They are also, respectively, Director and Assistant Director of the Centre for Not-for-profit and Publicsector Research at the University. 


\section{INTRODUCTION}

Since the 1940s there has been a massive expansion in the role of the public sector across many Organisation for Economic Co-operation and Development (OECD) countries. This was driven in the main by rising expectations and the demand for greater equality. It was felt that in order to participate in society, citizens had to have reasonable access to services such as health, education and housing (Sanderson, 1996). The public sector consists of organisations that are owned and operated by government; organisations that exist to provide goods and services for a country's citizens. In most countries, the operation of the public sector is widespread. However, the specifics of activities undertaken (and the size of the sector overall) varies, often aligned to a country's dominant political philosophy.

Typically, the provision of defence and law enforcement are almost always public goods provided by the public sector (where no one is excluded, regardless of their ability to contribute to funding the activity). Frequently, the public sector is also responsible for the delivery of services relating to education, health and infrastructure as public goods, although, in some situations, provisions of a service above a base minimum level may be private goods which depend on a consumer's ability to pay. What is particularly distinctive about public-sector organisations, and what makes them different from businesses, is that they are not-for-profit (although that does not preclude them from making a surplus), and they often have wide social and cultural goals that are central to what they do. In most countries, the sector is large, with the average percentage publicsector employment rate in OECD countries being approximately 19 per cent of the working population (OECD, 2015). For example, in the UK there are about 5.4 million people employed in the public sector, 16.4 per cent of all people in work (Office for National Statistics (ONS), 2019).

However, the sector across the globe is facing crisis on a number of fronts. New Public Management (NPM) ideas, initially introduced into the public sector in the 1980s (and claimed to have the potential to make government more efficient and effective), have been robustly challenged in terms of their tendency to undermine public values and their failure to deliver better services (Hood and Peters, 2004; Pollitt, 2007). NPM is a convenient, though rather loose, term that is used as shorthand for a set of broadly similar administrative doctrines that has dominated the reform agenda in the public sector in many countries. In particular, it stresses private-sector management styles, contract-based competitive provision and a focus on explicit formal measurable standards of performance related to output and outcomes (rather than inputs) (Hood 1991; 1995). Encouraged by an NPM philosophy, the rise in network arrangements in the public sector, often combining private-sector, public-sector and, even possibly, third-sector contributions (sometimes seen as a way of making more resources available to build public-sector capacity), has been criticised for fragmenting service delivery, reducing accountability and undermining service quality (Pollitt and Bouckaert, 2011; Shaoul et al., 2011).

In addition, the 'Great Recession' which began in 2008 as a mission to rescue the banking sector, has also had major impacts on public services and the creation of a public-sector crisis (Hodges and Lapsley, 2016). This triggered a period of austerity, and has continued to herald swingeing cuts in public-sector spending across a variety of fronts as governments have sought to control debt and reduce deficits (Hyndman and Lapsley, 2016). Calls for greater accountability and transparency (notwithstanding problems in defining these terms) have correlated with apparent reductions in trust (often brought on by scandals) in both arms of government and establishment figures (particularly politicians) and have encouraged the rise of populist movements (Inglehart and Norris, 2016; Skinner. and Clemence, 2017; Evans et al., 2018; Walker, 2018). Furthermore, in the UK and Europe, the uncertainty brought about by Brexit (Brexit being a shorthand way of referring to the UK's announced intention to leave the European Union - EU) has generated intense debate regarding the social and economic consequences of such a move (Parker, 2017). 
In this dynamic context, public-sector governance, accounting and accountability systems are heavily involved. At times they are used to shape and justify government responses to the crisis. The tools and techniques of accounting also frequently influence key actors' views on, and decisions relating to, the crisis. Indeed, the language of accounting and accountability (and its related tools and techniques) are often mobilised to provide frameworks for analysis and, occasionally, ammunition to promote particular approaches or counter arguments that challenge approaches being proposed. Calls for greater transparency and better governance are often met with responses related to the development of new, or the refreshing of old, accounting, accountability and governance processes. In this lead article to the Special Issue, and to reflect the breadth of this crisis, we focus on three (potentially overlapping) broad themes that appear in a number of the subsequent papers: NPM and performance management; NPM and accounting changes; and the impact of austerity and changed political realities.

\section{NPM AND PERFORMANCE MANAGEMENT}

Key aspects of NPM are the establishment of standards of performance (where performance is measured against defined benchmarks), and a focus on output and outcome measures - with emphasis being placed on what organisations are producing, not just on what they are spending. In discussions of these issues in public-sector settings, performance is often modelled by reference to a production (or logic) model utilising such terms as input, process, output, outcome and impact (The W. K. Kellogg Foundation, 2004). Driven by an NPM agenda, many public-sector organisations (and governments) have sought to develop targets which reflect a myriad of aspects of an organisation's performance and use them for control, decision-making and accountability purposes in, for example, education, policing, health and defence (Muller, 2018). Such performance-related initiatives emphasise the importance of quantification and calculative practices in the public sector, specifically in the context of a highly rational model of management behaviour. They often echo long-standing ideas connected to such writers as Drucker (1954) and Argenti (1989) and, borrowing from the business-sector literature, argue that the strategy of publicsector organisations should emerge from highly systematised forms of planning that embrace specific and quantified targets to support control and decision making (Efficiency Unit, 1988; HM Treasury, 2017).

However, the extent to which such tightly-coupled, metric-specific management processes are appropriate, or possible to construct, in the public sector is questionable. Even in the business sector, the efficacy of rational-management approaches, often facilitated through calculative-heavy information flows, is seen as highly problematic (Chandler and Plano, 1988; Mintzberg, 1994; Parker and Kohlmeyer, 2005). When used in the public sector, the criticisms are often much more frequent and much sharper. For example, it is often contended that such methods often lack appreciation of the political and social contexts into which these systems are introduced. Indeed, Broadbent and Guthrie (1992) argue that many of the accounting and reporting changes that are implemented in the public sector are often unevaluated, neglect the social side of organisations, deflect focus from key issues and may be detrimental to the best interests of society. Moreover, and specifically with respect to performance measurement, there is also a possible danger that in attempting to define a mission and objectives, and establishing targets and reporting performance against them, the whole practice will degenerate into a formal ceremony that has little impact on the behaviour of managers and lapse into a senseless ritual. As argued by Sharifi and Bovaird (1995):

' [] $\mathrm{t}$ might $\ldots$ be argued that in the public sector the potent symbol of performance orientation has helped to establish the myth that public sector organisations have a sense of direction and an explicable rationale for their actions. This myth is reinforced by the rituals of performance measurement and reporting.' (p. 477, emphasis in original text.) 
Furthermore, and possibly one of the most damaging aspects of a rise in the use of metrics, is the danger of overemphasising quantitative measures and deemphasising, or ignoring, qualitative factors in evaluation and decision making. This has been a long-standing criticism. Earl and Hopwood (1980) suggest that too much reliance by management on formal channels of communication (possibly including quantitative measures of performance) and mechanistic responses to the information provided may be inappropriate. They argue that in many organisations, especially those with high uncertainty about objectives and unclear cause and effect relationships (which are typical circumstances for many public-sector organisations), there is a need for less formal channels of information processing and greater use of subjective judgement. However, for a considerable time, many public-sector organisations (for example, hospitals, schools, police forces and universities) in a variety of countries have sought (or been forced) to develop 'tight' targets which reflect a myriad of aspects of their organisation's performance. These are then used for control, decision-making and accountability purposes. In particular cases, 'good' performance has been rewarded with substantial (financial and other) benefits, while inadequate performance is 'punished'. Driven largely by an NPM agenda and its associated rhetoric, official government publications promoting target setting often argue that the use of such metrics can lead to sharper, leaner, more-effective organisations, and organisations within which individuals can be motivated (or persuaded or, possibly in some cases, coerced) into behaving in particular ways.

However, a theme from a range of researchers reviewing performance management in the public sector is that, too often, organisations, rather than rely on the informed judgment of people familiar with the situation, inappropriately gather meaningless numbers and use them to guide actions. This often entails significant cost and frequently results in consequences that are not beneficial to the organisation itself or, more widely, to society as a whole. In the concluding paragraph to a book carrying the fascinating title of The Tyranny of Metrics (Muller, 2018) (a book which draws heavily on the public sector to illustrate its key contentions) it is argued that (p.183):

'In the end, there is no silver bullet, no substitute for actually knowing one's subject and one's organisation... Many matters of importance are too subject to judgement and interpretation to be solved by standardised metrics... Ultimately the issue is not about metrics versus judgement, but metrics as informing judgement, which includes knowing how much weight to give to metrics, recognising their characteristic distortions, and appreciating what can't be measured. In recent decades, too many politicians, business leaders, policymakers and academic officials have lost sight of that.'

For illustration purposes we provide one example from the UK, in a realm many of us may be familiar with: the university sector. A significant proportion of UK universities' income comes (directly and indirectly) from government. In this sector, in the UK and elsewhere, over many years, there has been a progressive movement towards an increased focus on performance measurement and quantifiable results for both individuals and organisations. The UK Government has moved, on the teaching side, towards the relatively recent introduction of a Teaching Excellence Framework (TEF) and, as far as research is concerned, towards the strengthening of the role of the more-established Research Excellency Framework (REF) (the last of which was concluded in 2014; the next being scheduled to finish in 2021). These exercises have now become the norm in the UK university sector, and their use is argued for and justified by government using the business-like logic of value for money, income generation, and productivity. Such terms are emphasised at the expense of 'pure' arguments related to a focus on education and students' development. For example:

'Higher education should deliver lasting value to graduates - and to the taxpayers underwriting the student loan system. We committed in our manifesto to ensure that 
universities deliver the best possible value for money for students, and this Green Paper sets out our approach.' (UK Department for Business Innovation \& Skills, 2015, p.8).

Given such changes in the sector, and reflecting government influence, universities are no longer seen by many as 'pure public-service' organisations, but rather as hybrid organisations, in which private-sector approaches are used and universities are urged, especially by central government masters, to be 'more commercial' (Guthrie and Neumann, 2007; Broadbent and Guthrie, 2008). This is the case in the UK and elsewhere (Parker and Guthrie, 2010; Narayan, 2019). In the UK, the REF process creates challenges in the ranking of published research (a contentious issue in many countries that have embraced metrics related to published research) and impact case studies. One feature of this is the highly-questionable tendency for universities to use ranking lists of journals to categorise the excellence of publications located in those journals. Certainly, this is an easier way to operate, and one which is likely to be embraced by central university managers who know little about academic research and wish to exert control over academics (Muller, 2018). The tensions between managerialism and the desire to protect traditional academic values are explored in both the German system (Conrath-Hargreaves and Wüstemann, 2019) and in the UK system (Du and Lapsley, 2019) in this Special Issue

With respect to the UK TEF process, concerns are equally strident. TEF seeks to assess the quality of undergraduate teaching in universities, with evaluations being based on statistics such as dropout rates, student satisfaction survey results and graduate employment rates. Universities are then rated as Gold ('consistently outstanding'), Silver ('high quality') and Bronze ('satisfactory quality'), or, if they do not meet a minimum 'quality' threshold, they will receive no award at all. A cacophony of concerns has been expressed, both within and outside of the sector, in relation to its operation and impact (Ashwin, 2018; Russell Group, 2019). Most striking is the question about whether the TEF really measures teaching quality at all, with there being no actual inspections of teaching inputting to the rating process; largely it is a paper-based exercise based on available data and written submissions from universities. Moreover, it is frequently argued that TEF is not difficult to 'game'. Perhaps most strikingly, the Royal Statistical Society (2019) published a view that it communicated to government, and more widely, that the TEF has statistical issues that are so major that it is (p.1) 'likely to mislead students who use TEF to inform their university choices'.

More widely, and reflecting on what is happening outside the UK, much accounting research focusing on universities has highlighted the strict measurement and audit culture which has developed. It is contended this has led to counter-productive outcomes, and the managerial oversight of academic work has reached a critical tipping point (Craig et al, 2014). Parker (2011) has argued that while outputs and performance matter to academics and to the wider society, the issue of accountability for such cannot be separated meaningfully from clarity about the overall role of universities. With such an argument, it is suggested that relying on excessively close ties with business-like models (as reflected in NPM) is to imperil the core principles without which universities become merely adjuncts to corporate power. Previous research findings show that internal management control systems developed by universities themselves to reflect such metrication, tend to amplify the controls imposed by such numbers-heavy external evaluation exercises. Yet while these internal control systems may be accepted by some academics, they often cause a movement away from previously held academic values (Agyemang and Broadbent, 2015).

\section{NPM AND ACCOUNTING CHANGE}

In addition to a much sharper focus on the use of non-financial performance measures, another major area of change related to the influence of NPM has involved radical modifications in accounting and budgeting tools. These are often introduced with claims that such adjustments will support government in becoming 'modern' and 'business-like'. A major argument for their use is the assertion that these 'new' accounting and budgeting systems facilitate a more efficient and 
effective public sector (Chan, 2003; Likierman, 2003; National Audit Office, 2003). However, whether these changes are helpful or appropriate remains a moot point (Diefenbach, 2009; Hyndman and Lapsley, 2016). For example, as seen in this Special Issue, and with respect to the development of a hospital costing system in China, mismatches between private-sector accounting and management approaches and traditional public-sector accountability and governance arrangements can cause strains that undermine the potential positive impacts of the system (Cui et al., 2019).

Such modifications have frequently involved a significant and progressive movement away from traditional public-administration accounting and budgeting systems, in favour of businesslike NPM-type accounting tools and ideas (Hyndman et al., 2014). Albeit the way in which this has occurred, and the extent to which movement along a NPM-accounting and budgeting continuum has been embraced, varies by country (Pollitt and Bouckaert, 2011), the direction of travel in many countries is similar. Aspects of it typically involve: moves from cash-based to accrual-based accounting systems (with, in its most extreme form, the adoption of IFRS principles and the production of consolidated accounts for the whole of the public sector); and adjustments in the budgeting system from cash to accruals, and from strict annul budgets with no ability to carryforward unspent amounts, to more flexible systems. However, as shown in the Hyndman et al. (2019) paper included in this Special Issue which considers accounting-system change in three countries (Austria, Italy and UK) over three decades, changes are often carried out, argued and interpreted differently depending on jurisdiction.

Accrual accounting is often presented as superior to cash accounting on the basis of arguments such as: traditional cash-based accounting systems have inbuilt biases against rational capital investment; and accrual accounting provides a more accurate basis for determining cost see International Federation of Accountants (2003) for a fuller discussion. Proponents of such systems frequently suggest that accrual accounting can provide accurate, true, objective information to support rational, objective-focused decision making. In addition, the auditing of such information against best practice guidance is meant to give external users confidence in the messages that such financial communications convey. However, the ability of key decision makers (such as politicians and managers) in public-sector settings to understand and utilise this (often fairly complex) information is frequently given limited consideration. Moreover, using earningsmanagement techniques originating in private-sector settings, public-sector managers can bias the financial numbers for their own purposes; with even the audit requirement not acting as a sufficiently disciplining force. Evidence of this is included in this Special Issue with respect to UK hospital trusts (Greenwood and Zhan, 2019). Overall, such practices have the potential to undermine trust.

While some (particularly professional accountants and their acolytes) may appreciate the technical aspects of the adoption of accrual accounting, accrual-accounting changes are meant to have a much wider constitutional influence relating to political control and political decision making (Newberry, 2015). Decisions, of both a managerial and a political nature, are meant to be made, performance is meant to be evaluated and political oversight is meant to be exercised using this new 'modern' accounting information. However, this presents problems. Many politicians and public-sector managers view accrual accounting as unreasonably complex, very difficult to understand and lacking a focus on key issues central to the public sector (Heald and Georgiou, 1995; Ezzamel et al., 2007; Connolly and Hyndman, 2011). Furthermore, it is frequently argued that the benefits of applying accrual accounting in a public-sector setting often have not been justified, and are difficult to justify (Connolly and Hyndman, 2006; Lapsley et al., 2009). In addition, and perhaps most crucially with respect to the role of politicians, it is suggested that accrual accounting uses very sophisticated 'expert talk', which has the potential to undermine democratic accountability (Ezzamel et al., 2005). These themes have echoes across a range of countries where accrual-accounting systems have been proposed and/or implemented (see: Brusca Alijarde, 1997; Guthrie, 1998; ter Bogt, 2004; Newberry and Pont-Newby, 2009). 
In the realm of budgeting, major NPM-related changes have also taken place in many countries. Again, the intensity and detail of these modifications have varied by country. Typically, these have involved: greater use of accrual (rather than merely cash) information in the budgeting process; clearer connections between budgets and performance measures; less emphasis on singleperiod plans; and more flexibility regarding carrying forward any underspends. For example, in the UK the move from cash budgeting to resource (accrual) budgeting was announced in the mid1990s and was 'live' by 2003. In addition, annuality (the requirement of budget allocations to be spent by the financial year-end or be surrendered to the centre) was abolished in 1997 at central government departmental level with end-year flexibility (EYF) being permitted (allowing the carry forward of unspent resources from one year to the next). However, as a consequence of financial pressures, this flexibility was removed in 2011. In addition, in a bid to provide greater long-term focus, in 1998, Treasury-led Spending Reviews were initiated to set firm and fixed spending budgets over several years for each government department rather than rely on single-period budgeting. Comparable changes, albeit at different times and with different intensities and varying emphases, were also introduced in other jurisdictions (Wanna et al., 2010).

The bedding down of announced changes regarding budgets has often proved problematic. Various reasons for this include: the unwillingness of central government to release freedoms to lower levels; an embedded culture of short-term planning; a lack of comfort with both the technical aspects of accrual budgeting and the impact of imposed-related performance targets; and the effect of unanticipated external financial pressures (Meszarits and Seiwald, 2008; Wanna et al., 2010). For example, in the UK when annuality was apparently abolished in 1997 (to be replaced by EYF), it was never 'cascaded' down the organisational levels and its apparent flexibility was never experienced by the majority of public-sector managers. In effect, little change took place (Hyndman et al., 2007)

Many governments have made major adjustments to their accounting and budgeting systems. The articulated rationale for these often resonates with NPM arguments connected to the idea of better information for decision making and control, and linking this to a more effective, more efficient and more accountable public sector. While, in many jurisdictions, such changes were pushed from the centre (based on ideas of making the public sector 'modern'), often a lack of belief in the benefits of system changes by those who have to use them, and a lack of understanding of the technical nature of the new systems, created problems. Indeed, what may be the net effect of many of these adjustments, given the manner in which they have been introduced and used, is that merely incremental (rather than radical) alterations in public-sector accounting and budgeting systems have occurred. This is where systems have changed, although the 'interpretive schemes', or the way people make decisions and think about issues, has remained largely unaltered (Greenwood and Hinings, 1993; Liguori and Steccolini, 2012; Hyndman and Liguori, 2018). Such a scenario, as is evidenced in much of the research, is likely to breed confusion.

\section{THE IMPACT OF AUSTERITY AND CHANGED POLITICAL REALITIES}

A period of austerity, following the worldwide financial crisis of 2008 (The Great Recession), heralded swingeing cuts in public-sector spending across a range of services. This was the case in many countries as governments sought to control debt and reduce deficits. While the scale and timing of the recession varied from country to country, the bailing out of banks was widespread and this led to major challenges relating to the financing of public debt and the (perceived) necessity to reduce other public expenditure. Perhaps, ironically, the public-sector funding crisis could be seen as a result of private-sector practice failure which, in an NPM environment, is often viewed by governments as something that the public sector should be encouraged to embrace (Hopper, 1986; Hodges and Lapsley, 2016).

Austerity refers to the adoption of policies aimed at reducing government budget deficits through, for example, spending cuts and tax increases. This is meant to achieve a deficit 
reduction by bringing government revenues closer to government expenditures. In the UK, the austerity programme included, among other things, reductions in welfare spending, the cancellation of major capital-expenditure programmes in health and education, and declines in (or curtailment of) a range of local-authority programmes. In addition, it also led to an increase in taxation, particularly with respect to value-added (or goods and services) tax. This programme has been described as the most crippling economic downturn since the Great Depression of the 1930s (Albers and Jonung, 2010).

The effects of such austerity policies have proved contentious and the policies have received criticism from a variety of politicians and economists. For example, the influence of austerity in the UK National Health Service, and reflections on whether previously entered into Public Private Partnership arrangements hinder the provision of future health care, is explored by Hellowell et al. (2019) in this Special Issue. It has also been argued that austerity has: impacted on child poverty and massively increased the necessity for food banks (Mueller, 2019); caused major reductions in the affordable housing programme (The Guardian, 2015); and resulted in significant reductions in local-authority spending (and service provision) in areas such as refuse collection, road maintenance and libraries (Local Government Association, 2019). Moreover, within this Special Issue, and within a context of austerity, Heald and Wright (2019) explore the calculation and impact of the UK's final Brexit bill for departing the EU. In particular, they examine the use of accounting (and other) numbers with respect to the UK's negotiating position relating to the possible charge. Other countries have been equally affected. For example, many EU countries have experienced similar (or even more intense) public-sector expenditure (and service) cuts. Jobs have been lost and wages have stagnated (BBC, 2012). Given the Great Recession, Greece, Ireland and Portugal each received massive bailouts from the EU and the International Monetary Fund. With such bailouts having to be financed, this put substantial additional pressure on public-sector service provision.

As a consequence of such programmes, anti-austerity movements in a number of countries emerged, resulting in mass public demonstrations, especially in 2011 and 2012, and major social and political instability (Adams, 2011; Donadio and Sayare, 2011). Leitmotifs relating to these groups included claims that governments were: imposing severe spending cuts too quickly and without appropriate consultation or consideration of impact; and were unfairly targeting cuts at the working class, while financial institutions (particularly those perceived as responsible for the crisis) were not adequately 'punished' (Poinasamy, 2013). Such movements contributed to the rise of populism; the idea that society is separated into two groups at odds with one another - the 'pure people' and the 'corrupt elite' (Canovan, 2004). Populist leaders often suggest he/she represents the unified 'pure people', and stands in opposition to an enemy (often embodied by the current system). The impact of this politically was, for example, clearly seen in the elections as president of Donald Trump in the USA and Rodrigo Duterte in the Philippines, the increased popularity of Jeremy Corbyn in the UK (with him being confirmed as leader of the Labour party in 2015) and the rise of Italy's Five-star movement (Burgen, 2015). Indeed, such populist ideas also came clearly to the fore in the UK Brexit referendum debate (2016) that resulted in the UK voting to leave the EU; albeit, at the time of writing, this process has still to be completed (Wheeler et al., 2019). Such changes have heralded, or will, going forward, have the potential to herald, significant adjustments in public-sector service provision and increasing instability in the public-sector and wider-social environments.

\section{CONCLUDING COMMENTS ABOUT THE SPECIAL ISSUE}

The public sector is critical for many reasons; it is also extensive in most countries. On average it accounts for about 19 per cent of all employment in OECD countries; it can encourage and facilitate important social, cultural and economic objectives. Although amounts spent and patterns of expenditure vary by country, social welfare, health, education and defence are typically the main 
areas of public-sector spend in many OECD countries. Smaller proportions of spend are often allocated to such areas as policing, transport, housing and industry/ agriculture. Public-sector organisations are (or perhaps, should be) very different from private-sector organisations. They have missions that are rarely focussed on profit generation. As well as underpinning broad economic goals, they often emphasise social and cultural values, frequently related to protecting, or providing public goods to, all citizens, or at least the most-needy or vulnerable citizens in our society. Traditionally (albeit changes are afoot), they have been administered using well-established public-administration principles and governance norms concerned with partnering, rather than controlling. Such organisations are often admired and appreciated by the societies which they serve; for example, with respect to the NHS in the UK.

However, as we have seen, the sector faces crisis, difficulties and dangers. The impact of NPM (business-like) ideas, tools and techniques has, at times, steered the sector in ways that many see as unhelpful. With respect to performance management, numerous performance frameworks that have been used have resulted in unintended and negative (although possibly predictable) consequences (Muller, 2018). Arguably, these have not served society well. Some of the new (largely private-sector inspired) accounting tools and approaches that have been introduced have resulted in accounting and budgeting systems that have changed (incremental change), but, at times, without any parallel (and hoped-for) changes in the 'interpretive schemes' of individuals (ways of understanding and using the information). Such is likely to undermine the high-goals of introducing them in the first place (whether or not they were particularly appropriate). Finally, the impact of the Great Recession, and the consequent perceived need for austerity, has caused great social unrest and political instability. This has resulted in major public-sector cutbacks that have had to be managed, often via the use of these new NPM accounting tools. Overall, austerity, and the spending choices that it has triggered, has undermined trust in the establishment (which has tended to destabilise the smooth functioning of society).

This Special Issue provides a range of empirical and theoretical contributions from a wide variety of research perspectives. It provides an opportunity to reflect on some of the key causes of crisis in the public sector and explores them in the context of accounting, accountability and governance. The contributions provide, not only evidence of the impact of, and response to, the crisis, but also suggest the appropriateness of certain approaches as ways of reducing the likelihood of crisis. A period of crisis provides a chance to evaluate and reflect. Hopefully, this Special Issue highlights the importance of focusing on the public sector as the subject of our research. The conducting and subsequent dissemination of theoretically-informed and rigorous empirical analysis (and critical thinking) in the area is essential. This can be used as a basis for judging proposed (and even previously implemented) changes and ideas, as well as supporting policy makers and decision makers as they grapple with the challenges facing the public sector. In addition, aspects of the Special Issue can be drawn upon to counter what, at times, seems like a pervasive and continuing momentum towards the implementation of managerial and market 'solutions' in a sector where, frequently, these may not be appropriate, and where their adoption may make the emergence of crisis more likely.

\section{REFERENCES}

Agyemang, G. and J. Broadbent (2015), 'Management Control Systems and Research Management in Universities', Accounting, Auditing \& Accountability Journal, Vol. 28, No. 7, pp. 1018-1046.

Adams, W.L. (2011), 'Anti-Cuts "March for the Alternative" Draws 500,000 Protesters in London', Time, 26 March, retrieved from: http:/ / newsfeed.time.com/2011/03/26/anti-cuts-march-forthe-alternative-draws-500000-protestors-in-london/ 
Albers, R. and L. Jonung (2010), 'Major Crises: Historical Comparisons to the Great Depression and the Classical Gold Standard', paper presented at the 6th Eurostat Colloquium, Luxembourg, 26-29 September.

Argenti, J. (1989), Practical Corporate Planning, Unwin Hyman, London.

Ashwin, P. (2018), 'TEF 2018: Can Students Trust the Gold Standard?' Times Higher Education, 6 June, retrieved from: https://www.timeshighereducation.com/blog/tef-2018-can-studentstrust-gold-standard

Broadbent, J. and J. Guthrie (1992), 'Changes in the Public Sector: A Review of 'Alternative' Accounting Research', Accounting, Auditing \& Accountability Journal, Vol. 5, No. 2, pp. 3-31.

Broadbent, J. and J. Guthrie, (2008), 'Public Sector to Public Services: 20 years of "Contextual Accounting Research"', Accounting, Auditing \& Accountability Journal, Vol. 21, No. 2, pp. 129169.

Brusca Alijarde, M. I. (1997), 'The Usefulness of Financial Reporting in Spanish Local Governments', Financial Accountability \& Management, Vol. 13, No. 1, pp. 17-34

Burgen, S. (2015), 'Thomas Piketty: Rise of Anti-austerity Parties Good News for Europe', The Guardian, 12 Jan, retrieved from:

https://www.theguardian.com/business/2015/jan/12/thomas-piketty-austerity-europegreece-spain

Canovan, M. (2006), 'Populism for Political Theorists?', Journal of Political Ideologies, Vol. 9, No. 3, pp. 241-252

Chan J. (2003), 'Government Accounting: An Assessment of Theory, Purposes and Standards', Public Money \& Management, Vol. 23, No. 1, pp. 13-20.

Chandler, R.C. and J.C. Plano (1988), The Public Administration Dictionary, ABC-CLIO, Santa Barbara.

Connolly, C. and N. Hyndman (2006), 'The Actual Implementation of Accruals Accounting: Caveats From a Case Within the UK Public Sector', Accounting, Auditing \& Accountability Journal, Vol. 19, No. 2, pp. 272-290.

Connolly, C. and N. Hyndman (2011), 'Accruals Accounting in the Public Sector: A Road Not Always taken’, Management Accounting Research, Vol. 22, No. 1, pp. 26-45.

Conrath-Hargreaves, A. and S. Wüstemann (2019), 'Managing Multiple Institutional Logics and the use of Accounting: Insights from a German Higher Education Institution', Abacus, Vol. 55, No. 3, pp. xx-xx

Craig, R., J. Amernic and D. Tourish (2014), 'Perverse Audit Culture and Accountability of the Modern Public University', Financial Accountability \& Management, Vol. 30, No. 1, pp. 1-24.

Cui, X., P. Li, M. Ai-Sayed and S. Zhou (2019), 'China's healthcare costing in times of crisis: conflicts, interactions and hidden agendas', Abacus, Vol. 55, No. 3, pp. xx-xx

Department for Business Innovation \& Skills (2015), Fulfilling Our Potential. Teacbing Excellence, Social Mobility and Student Choice, Her Majesty's Stationery Office, London.

Diefenbach, T. (2009), 'New Public Management in Public Sector Organizations: The Dark Sides of Managerialistic 'Enlightenment”, Public Administration, Vol. 87, No. 4, pp. 892-909.

Donadio, R. and S. Sayare (2011), 'Violent Clashes in the Streets of Athens', New York Times, 29 June, retrieved from: https://www.nytimes.com

Drucker, P. (1954), The Practice of Management, Harper and Row, New York.

Du, J. and I. Lapsley (2019), 'The Reform of UK Universities: A Management Dream, an Academic Nightmare?', Abacus, Vol. 55, No. 3, pp. xx-xx

Earl, M.J. and A.G. Hopwood (1980), 'From Management Information to Information Management', in H.C. Lucas et al. (eds.), The Information Systems Environment, North-Holland, New York.

Efficiency Unit (1988), Improving Management in Government: The Next Steps. A Report to the Prime Minister, Her Majesty's Stationery Office, London. 
Evans, M., G. Stoker and M. Halupka (2018), 'Australians' Trust in Politicians and Democracy Hits an All-time low', The Conversation, December, retrieved from:

https:/ / theconversation.com/australians-trust-in-politicians-and-democracy-hits-an-all-timelow-new-research-108161

Ezzamel, M., N. Hyndman, A. Johnsen, I. Lapsley and J. Pallot (2005), 'Conflict and Rationality: Accounting in Northern Ireland's Devolved Assembly', Financial Accountability \& Management, Vol. 21, No. 1, pp. 33-55.

Ezzamel, M., N. Hyndman, A. Johnsen, I. Lapsley, I. and J. Pallot (2007), 'Experiencing Institutionalization: The Development of New Budgets in the UK Devolved Bodies', Accounting, Auditing \& Accountability Journal, Vol. 20, No. 4, pp. 11-40.

Guthrie, J. and R. Neumann (2007), 'Economic and Non-financial Performance indicators in Universities', Public Management Review, Vol. 9, No. 2, pp. 231-252.

Greenwood, M. and R. Zhan (2019), 'Audit adjustments and public sector audit quality', Abacus, Vol. 55, No. 3, pp. xx-xx

Greenwood, R., and C.R. Hinings (1993), 'Understanding Strategic Change: The Contribution of Archetypes', The Academy of Management Journal, 36(5), 1052-1081.

Guthrie, J. (1998), 'Application of Accrual Accounting in the Australian Public Sector - Rhetoric or Reality', Financial Accountability \&Management, Vol. 14, No. 1, pp. 1-19.

Heald, D. and G. Georgiou (1995), 'Resource Accounting: Valuation, Consolidation and Accounting Regulation', Public Administration, Vol. 73, No. 4, pp. 571-579.

Heald, D. and I. Wright (2019), 'The United Kingdom's Exit Bill from the European Union: Insights from Modes of Accounting', Abacus, Vol. 55, No. 3, pp. xx-xx

Hellowell, M., A. Stafford and P. Stapleton (2019), 'Austerity and Hospitals in Deficit: Is PPP Termination the answer?', Abacus, Vol. 55, No. 3, pp. xx-xx

Hodges, R. and I. Lapsley (2016), 'A Private Sector Failure, a Public Sector Crisis - Reflections on the Great Recession', Financial Accountability \& Management, Vol. 32 No. 3, pp. 265-280.

HM Treasury (2017), Guidance: The Government's Planning and Performance Framework, HM Treasury, retrieved from: https://www.gov.uk/government/publications/planning-and-performanceframework/the-governments-planning-and-performance-framework\#Annual-Reports-andResource-Accounts

Hood, C. (1991), 'A Public Management for all Seasons?', Public Administration, Vol. 69, No. 1, pp. 3-19.

Hood, C. (1995), 'The 'New Public Management' in the 1980s: Variations on a Theme?', Accounting, Organizations and Society, Vol. 20, Nos. 1/2, pp. 93-109.

Hood, C. and G. Peters (2004), 'The Middle Aging of New Public Management: Into the age of Paradox?', Journal of Public Administration Research and Theory, Vol. 14, No. 3, pp. 267-282.

Hopper, T. (1986), 'Private Sector Problems Posing as Public Sector Solutions', Public Finance \& Accountancy, 3 October, pp. 11-13.

Hyndman, N., R. Jones and M. Pendlebury (2007), 'An Exploratory Study of Annuality in the UK Public Sector: Plus ça Change, Plus C'est la Même Chose?', Financial Accountability \& Management, Vol. 23, No. 2, pp. 215-237.

Hyndman, N. and I. Lapsley (2016), 'New Public Management: The Story continues', Financial Accountability \& Management, Vol. 32, No. 4, pp. 385-408.

Hyndman, N. and M. Liguori (2018), 'Achieving Radical Change: A Comparative Study of Publicsector Accounting in Westminster and Scotland', Accounting, Auditing \& Accountability Journal, Vol. 31, No. 2, pp. 428-455.

Hyndman, N., M. Liguori, R. Meyer, T. Polzer, S. Rota and J. Seiwald (2014), 'The Translation and Sedimentation of Accounting reforms. A Comparison of the UK, Austrian and Italian Experiences', Critical Perspectives on Accounting, Vol. 25, Nos.4/5, pp. 388-408. 
Hyndman, N., M. Liguori, R.. Meyer, T. Polzer, J. Seiwald and I. Steccolini (2019), 'Justifying Public-sector Accounting Change From the Inside: Ex-post Reflections From Three countries', Abacus, Vol. 55, No. 3, pp. xx-xx

Inglehart, R.F. and P. Norris (2016), 'Trump, Brexit, and the Rise of Populism: Economic Havenots and Cultural Backlash', HKS Working Paper No. RWP16-026, retrieved from: https://ssrn.com/abstract=2818659 or http://dx.doi.org/10.2139/ssrn.2818659

International Federation of Accountants (IFAC) (2003), Transition to the Accrual Basis of Accounting: Guidance for Governments and Governmental Entities, IFAC, New York.

Lapsley, I., R. Mussari and G. Paulsson (2009), 'On the Adoption of Accrual Accounting in the Public Sector: A Self-evident and Problematic Reform', European Accounting Review, Vol. 18, No. 4, pp. 719-723.

Likierman A. (2003), 'Planning and Controlling UK Public Expenditure on a Resource Basis', Public Money \& Management, Vol. 23, No. 1, pp. 45-50.

Logal Government Association (LGA) (2019), LGA briefing: Debate on Local Government Funding, House of Commons, 15 January, retrieved from: https:/ /www.local.gov.uk/parliament/briefingsand-responses/lga-briefing-debate-local-government-funding-house-commons

Liguori, M. and I. Steccolini (2012), 'Accounting Change: Explaining the Outcomes, Interpreting the Process', Accounting, Auditing \& Accountability Journal, Vol. 25 No.1, pp.27-70.

Meszarits, V. and J. Seiwald (2008), Budgetary Reform in Austria: Towards Tighter Coupling Within the Financial and Management System, Federal Ministry of Finance, Vienna.

Mintzberg, H. (1994), The Rise and Fall of Strategic Planning, Simon and Schuster, New York.

Muller, J.Z. (2018), The Tyranny of Metrics, Princeton University Press, Princeton.

Mueller, B. (2019), 'What is Austerity and How has it Affected British Society?', 24 February, The New York Times, retrieved from: https://www.nytimes.com/2019/02/24/world/europe/britain-austerity-may-budget.html

Narayan, A.K. (2019), 'The Development and use of Performance Measures in New Zealand Tertiary Education Institutions', Accounting History, pp. 1-26, DOI: $10.1177 / 1032373219842383$

National Audit Office (2003), Managing Resources to Deliver Better Public Services (Report by the Comptroller and Auditor General), HC 61-I Session 2003-2004, The Stationery Office, London.

Newberry, S. (2015), 'Public Sector Accounting: Shifting Concepts of Accountability', Public Money \& Management, Vol. 35, No. 5, pp. 371-376.

Newberry, S. and S. Pont-Newby (2009), 'Whole of Government Accounting in New Zealand: The Ownership Form of Control', Public Money \& Management, Vol. 29, No. 4, pp. 235-242.

Office for National Statistics (ONS) (2019), Statistical Bulletin: Public Sector Employment, UK: December 2018, ONS, London.

Organisation for Economic Co-operation and Development (OECD) (2015), Employment in the Public Sector: Government at a Glance 2015, OECD Publishing, Paris.

Parker, G. (2017), 'Theresa May Braced for a Fall as Brexit Tests Loom', Financial Times, 5 July, retrieved from://www.ft.com/content/02f15952-6099-11e7-8814-0ac7eb84e5f1

Parker, L. (2011), 'University Corporatisation: Driving Redefinition', Critical Perspectives on Accounting, Vol. 22 No. 4, pp. 434-50.

Parker L. and J. Guthrie (2010), 'Business Schools in an age of Globalization', Accounting, Auditing \& Accountability Journal, Vol. 23, No.1, pp.5-13.

Parker, R.J. and J.M. Kohlmeyer (2005), 'Organizational Justice and Turnover in Public Accounting Firms: A Research Note', Accounting, Organizations and Society, Vol. 30, No. 4, pp. 357-369.

Poinasamy, K. (2013), The True Cost of Austerity and Inequality (UK Case Study), Oxfam GB, Oxford.

Pollitt, C. (2007), 'The New Public Management: An Overview of its Current Status', Administratie si Management Public, August, pp. 110-115, Public Management Institute, Katholieke Universiteit Leuven, Belgium. 
Pollitt, C. and G. Bouckaert (2011), Public Sector Reform. A Comparative Analysis: New Public Management, Governance, and the Neo-Weberian State, 3rd ed., Oxford University Press: Oxford.

Russell Group (2019), Russell Group Response to the Independent Review of TEF, retrieved from: https://www.russellgroup.ac.uk/media/5746/rg-response-to-the-independent-review-of-tefcall-for-views-final.pdf

Royal Statistical Society (2019), Concerns Regarding the Teaching Excellence and Student Outcomes Framework (TEF), retrieved from: https://www.statisticsauthority.gov.uk/wpcontent/uploads/2019/03/Letter-from-RSS-to-Ed-Humpherson-TEF.pdf

Sanderson, I. (1996), 'Evaluation, Learning and the Effectiveness of Public Services', International Journal of Public Sector Management, Vol. 9, Nos. 5/6, pp. 90-106.

Shaoul, J., A. Stafford and P. Stapleton (2011), 'NHS Capital Investment and PFI: From Central Responsibility to Local Affordability', Financial Accountability \& Management, Vol. 27, No. 1, pp. 1-17.

Sharifi, S. and T. Bovaird (1995), 'The Financial Management Initiative in The UK Public Sector: The Symbolic Role of Performance Reporting', International Journal of Public Administration, Vol. 18, Nos. 2/3, pp. 467-490.

Skinner, G. and Clemence, M. (2017), The Ipsos MORI Veracity Index, Ipsos Public Affairs, UK, retrieved from: https://www.ipsos.com/ipsos-mori/en-uk/politicians-remain-least-trustedprofession-britain

ter Bogt, H. J. (2004), 'Politicians in Search of Performance Information? Survey Research on Dutch Aldermen's Use of Performance Information', Financial Accountability \& Management, Vol. 20, No. 3, pp. 221-252.

The Guardian (2015), 'How do you fix a Housing Crisis in a Time of Austerity?' 11 Mar 2015, The Guardian, retrieved from: https://www.theguardian.com/housingnetwork/2015/mar/11/housing-crisis-time-austerity

The W. K. Kellogg Foundation (2004), Using Logic Models to Bring Together Planning, Evaluation and Action: Logic Model Development Guide, The W.K. Kellogg Foundation, Battle Creek, MI.

Walker, D. (2018), 'Capita Marks the Beginning of the end for Public Service Contracting', The Guardian, 31 Jan, retrieved from: https://www.theguardian.com/public-leadersnetwork/2018/jan/31/capita-beginning-end-public-service-contracting-councilsprivatisation

Wanna, J, L. Jensen and J. de Vries (2010), The Reality of Budgetary Reform in OECD Nations. Trajectories and Consequences, Edward Elgar: Cheltenham and Northampton, Massachusetts.

Wheeler, B., P. Seddon and R. Morris (2019), 'Brexit: All you Need to Know About the UK Leaving the EU', $B B C$, retrieved from: https://www.bbc.co.uk/news/uk-politics-32810887 